\title{
ESTRATÉGIAS DIGITAIS DOS POPULISMOS DE ESQUERDA E DE DIREITA: BRASIL E ESPANHA EM PERSPECTIVA COMPARADA
}

\section{THE DIGITAL STRATEGIES OF RIGHT-WING AND LEFT-WING POPULISM: BRAZIL AND SPAIN IN COMPARATIVE PERSPECTIVE}

\section{Theófilo Rodrigues* Daniel Ferreira*}

\section{RESUMO}

A presente pesquisa identifica duas práticas distintas de relacionamento do populismo com as mídias digitais nesse início do século XXI: a horizontal e a vertical. A partir da análise comparada dos casos de Bolsonaro no Brasil e do Podemos na Espanha, representantes de um populismo de direita e de um populismo de esquerda, respectivamente, observouse como cada uma dessas práticas políticas lida com as mídias digitais. $\mathrm{O}$ populismo de direita brasileiro opera uma mobilização social vertical, baseada em mensagens em redes sociais como Facebook, Whatsapp e Twitter que informam as agendas a serem seguidas por seu eleitorado. Assim, o eleitorado é receptor, mas também divulgador da agenda. Além disso, a prática das Fake News é crucial na tática de construção das narrativas empregada por Bolsonaro. O populismo de esquerda do Podemos, ao contrário, opera uma tática horizontal com a experimentação de práticas deliberativas nas redes sociais. O eleitorado é receptor e construtor da agenda.

Palavras-chave: populismo; política comparada; mídias digitais.

\section{ABSTRACT}

This paper identifies two different practices of relationship between populism and digital media in the early 21 st century: one more horizontal the other vertical. Herein, it compared the cases of Bolsonaro in Brazil with Podemos in Spain, the former a right populism and the latter a leftist one, and how each one deals with digital media. Brazilian right populism operates a vertical social mobilization, based on messages in social networks like Facebook, Whatsapp and Twitter which inform the agenda to be followed by the electorate. It means that the electorate is a receptor and an agenda spreader. Also, Bolsonaro activates this technique from a fake news tactics much more crucial to the building of his narrative than

\footnotetext{
*Universidade doEstado do Rio deJaneiro, UERJ, Rio deJaneiro, RJ, Brasil.theofilomachadorodrigues@ gmail.com

Orcid: https://orcid.org/0000-0003-1709-1546

** Universidade do Estado do Rio de Janeiro, UERJ, Rio de Janeiro, RJ, Brasil. danielhmf@iesp.uerj.br Orcid: https://orcid.org/0000-0003-2129-6050
} 
any other movement. By contrast, Podemos' Left populism acts tensioning a vertical tactic with the experimentation of horizontal and deliberative practices in social networks. Here, electorate is a receptor and an agenda builder.

Keywords: populism; comparative politics; digital media.

\section{INTRODUÇÃO}

Vivemos uma era de transição já muito bem notada pela literatura especializada. Seja por mudanças tecnológicas que afetaram os meios de comunicação, seja por alterações na própria estrutura social derivada do mundo do trabalho, o fato é que a sociedade do século XX já não é a mesma nesse início do século XXI. Sociedade pós-industrial (TOURAINE, 1970), sociedade de redes (CASTELLS, 2009), sociedade pós-material (INGLEHART, 2001), sociedade pósfordista (NEGRI e HARDT, 2014), sociedade pós-moderna (HARVEY, 2007) e sociedade pós-democrática (RANCIÈRE, 1999) são apenas algumas das muitas expressões utilizadas para a interpretação desse novo mundo, ou, ao menos, dessa nova transição contemporânea. Em decorrência desse novo cenário internacional ou em resposta a ele - emerge aquilo que uma parcela da literatura definiu como o "momento populista" (MOUFFE, 2019), com forte instrumentalização das mídias digitais.

A presente pesquisa acredita que há uma relação de afinidade eletiva entre o assim chamado "momento populista" e as novas tecnologias de informação e comunicação. Entretanto, como a própria literatura observa a pluralidade de populismos (MOUFFE, 2019), também nos questionamos se essa relação não seria diferente dependendo da posição ideológica. Procuramos abordar essa questão a partir da comparação entre dois estudos de caso de sucesso eleitoral. No primeiro caso, nossa análise aborda o populismo de Bolsonaro e suas principais estratégias de campanha. No segundo caso, analisa-se o surgimento do Podemos e sua estratégia de consolidação como força política.

O artigo está estruturado em três seções. A primeira seção traz uma abordagem teórica sobre os conceitos que norteiam a prática nos novos populismos no século XXI como a ideia de "democracia de público" de Manin, de hegemonia de Gramsci e de populismo de Laclau. A segunda seção identifica o modo como o populismo de direita de Bolsonaro no Brasil se apropriou das mídias digitais, com ênfase no uso das chamadas Fake News, para uma mobilização social de tipo vertical. Por fim, a terceira seção apresenta o caso do populismo de esquerda do Podemos na Espanha, em que a mobilização social via mídias digitais se dá de forma participativa e deliberativa, ou, como preferimos categorizar, de modo horizontal. 


\section{DEMOCRACIA DE PÚBLICO, POPULISMO E HEGEMONIA}

No campo da teoria política, uma das vozes que melhor identificou essa transição do século XX para o XXI, em particular no que diz respeito ao modelo de representação, foi a de Bernard Manin (1995). Para Manin, ao longo da história houve três tipos-ideais de governo representativo: o "parlamentar"; a "democracia de partido"; e a "democracia de público". Próprio do século XIX, os principais atores do período do governo parlamentar foram os notáveis. Esse período representa bem aquilo que na teoria política de Burke conhecemos como o "mandato representativo", ou seja, um certo distanciamento entre eleitor e eleitores. Com a ampliação do eleitorado derivado da extensão do sufrágio característico da virada do século XIX para o XX, os partidos políticos se profissionalizaram. Esse é o mundo de Michels, em que a burocratização das organizações partidárias e das redes de militantes é uma exigência para a mobilização de um eleitorado mais numeroso. Na leitura de Manin, há aqui uma primeira metamorfose do governo representativo que transita do tipo "parlamentar" para a "democracia de partido". "Nesse tipo de governo representativo, os partidos organizam tanto a disputa eleitoral quanto os modos de expressão da opinião pública (manifestações de rua, petições, campanhas pelos jornais)" (MANIN, 1995, p. 11). Esse foi o modelo bem conhecido do século XX. Contudo, em fins do século, sinais de uma nova metamorfose do governo representativo emergiram. Impulsionados pelos meios de comunicação de massas, as elites políticas passam a prescindir das burocracias partidárias e estabelecem canais diretos de comunicação com os eleitores. Nas palavras de Manin (1995, p. 13), "a democracia do público é o reinado do 'comunicador". Manin escreveu antes mesmo do advento das redes sociais na internet como as conhecemos hoje. Mas esse desenvolvimento tecnológico e suas consequências políticas apenas corroboraram a tese do autor.

Se concordarmos com a interpretação de Manin, vivemos na era da democracia de público. Mas também presenciamos, nesse início de século XXI, um outro tipo de fenômeno político, qual seja, o "momento populista" (MOUFFE, 2019). Na leitura que Laclau (2013) faz do fenômeno, este é uma forma discursiva inerente à política na qual as diferentes demandas sociais não atendidas são aglutinadas e representadas por um significante maior - que perde seu conteúdo interno. É a articulação dessas demandas não atendidas em torno de uma cadeia de equivalência que forma o "povo". Ao mesmo tempo, a construção do discurso estabelece uma fronteira agonística entre o "povo" e aqueles que impedem a realização daquelas demandas. 
A riqueza da leitura de Laclau reside em não impor um conteúdo ao populismo, mas sim em observá-lo apenas como um tipo específico de articulação política, que pode envolver conteúdos distintos. Assim, o populismo pode ser de esquerda ou de direita, de acordo com o modo como as demandas sociais foram organizadas e a fronteira agonística, delimitada. A definição de Stuart Hall para o "populismo autoritário" de Margaret Thatcher na Inglaterra remete ao populismo de direita. Segundo Hall (1988, p. 48, tradução nossa), o populismo autoritário "combina os temas ressonantes do conservadorismo ${ }^{1}$ orgânico - nação, família, dever, autoridade, padrões, tradicionalismo - com os temas agressivos de um neoliberalismo renovado - interesse próprio, individualismo competitivo, antiestatismo". Ao avaliar o populismo de direita de Donald Trump nos Estados Unidos, que define como um "populismo reacionário", Nancy Fraser (2019, p. 88) observa características como um "governo racista, anti-imigrantista e antiecológico". Já o populismo de esquerda é aquele que, em geral, o "povo" identifica-se com aquilo que Laclau e Mouffe (2015) chamam de "democracia radical" ou "um novo projeto hegemônico de esquerda", em que há uma articulação entre as lutas contra o sexismo, o racismo, a discriminação sexual e em defesa do meio ambiente com a luta dos trabalhadores.

É nesse contexto da "democracia de público" e do "momento populista" que as novas mídias digitais operam. Com a entrada na Era da Informação, os fluxos de informação e comunicação se tornam primordiais na organização da sociedade (CASTELLS, 2009). O seu maior pilar são as Novas Tecnologias de Informação e Comunicação, as NTICs, cujo impacto na política pode ser representado em três modificações sociais interligadas: redução do número de intermediários necessários para organizar uma mobilização (NUNES, 2015); densificação das redes sociais com a ampliação do número de laços entre os nós, devido aos meios de auto comunicação de massas (CASTELLS, 2009); e por fim, o aumento da individuação dos movimentos, ao criar um espaço de ação que estaria nos interstícios entre o público e o privado (CASTELLS, 2013; PLEYERS, 2017). As redes, ao ganharem importância como princípio de organização social, marcam uma mudança na modernidade, a partir da qual a colaboração voluntária se torna um mecanismo de coordenação de destaque, frente às épocas pretéritas mais baseadas no comando e nas trocas (DOMINGUES, 2013).

Esse processo faz eco à racionalização demográfica de que fala Gramsci (2015). Ao olhar para os Estados Unidos, Gramsci observa que a introdução da fordismo como meio de organização do trabalho é resultado da ausência de classes parasitárias, isto é, classes sem funções específicas no mundo da produção. Sem

1. Toryism, no original. 
essa "camada de chumbo" que se acumularia em torno do Estado, a racionalização permitiu que a "hegemonia" nascesse "na fábrica" e necessitasse apenas "de uma quantidade mínima de profissionais da política e da ideologia" para ser exercida (GRAMSCI, 2015, p. 247-248).

Portanto, a hegemonia civil, isto é, "a direção moral e política" do indivíduo (GRAMSCI, 2014, p. 62), apontada por Gramsci, em um sistema complexo, pode ser agora disputada e conduzida por uma quantidade mínima de intermediários, devido à racionalização demográfica que a coordenação em redes produziu. Graças às NTICs, há um deslocamento na própria necessidade de um centro, impondo que as lutas sejam conduzidas por uma multiplicidade de canais em paralelo às instituições convencionais produtoras de consenso. Nesse sentido, a perda do número de intermediários também levou a uma compressão da burocracia e das fórmulas formais.

A conjugação dos fatores acima assinalados - autocomunicação de massas e redução no número de intermediários políticos - modifica os canais de representação. $\mathrm{O}$ resultado é que a função de liderança passa a ser exercida não mais por uma chancela formal e disciplinada, mas na medida em que se é capaz de obter seguidores (NUNES, 2015, p. 3670; BAUMAN, 2000). No caso das redes sociais, ainda é possível compartilhar e viralizar os discursos e os seus produtores, promovendo maior capilaridade na difusão dos conteúdos e a sua intensificação em câmaras de eco que emergem dos próprios algoritmos que estruturam as redes (SUNSTEIN, 2007).

Com esse mecanismo, liderar - isto é, operar a hegemonia - torna-se a tarefa de produzir mais engajamentos e apelo discursivo. Nesse sentido, as NTICs se tornam ferramentas políticas que facilitam a operação populista, por permitir a eclosão de uma política com menos intermediários e a emergência de discursos polarizadores e aglutinadores de demandas. Entretanto, as táticas de engajamento, a forma e o conteúdo das informações mudam entre autoritários e democratas radicais.

\section{POPULISMO DE DIREITA: BOLSONARO E AS FAKE NEWS}

Não há muitas dúvidas de que o presidente Jair Bolsonaro representa no Brasil aquilo que definimos na seção anterior como um populismo de direita. Ao tratarem do então candidato à presidência no Brasil, Nancy Fraser e Mayra Cotta observaram que "a candidatura que celebra a ditadura militar e é entusiasta da tortura e da violência institucionalizada no Estado é a mesma candidatura que ataca 
as sexualidades não hétero e que não quer que gênero seja ensinado nas escolas" ${ }^{\prime \prime}$. Com efeito, há até mesmo quem prefira ir além, como Chantal Mouffe faz ao afirmar que no populismo de direita "há apenas uma pessoa que merece o título de fascista e é (Jair) Bolsonaro" ${ }^{\prime \prime}$. Segundo Mouffe, "o projeto de Bolsonaro é claramente um projeto que coloca em questão o Estado de Direito e as instituições da democracia pluralista", o que bastaria para defini-lo como fascista. Mas não é nosso objetivo alargar a discussão sobre essa possível característica fascista em sua práxis; antes, preferimos apenas partir da ideia de que Bolsonaro articula a prática do populismo de direita ou do populismo autoritário no Brasil.

Capitão reformado do exército brasileiro e deputado federal por sete mandatos consecutivos, entre 1991 e 2018, Jair Bolsonaro foi eleito presidente da República na eleição de outubro de 2018. Após ter passado por oito legendas, o militar finalmente filiou-se em 2018 num pequeno partido político sem qualquer expressão nacional, o PSL, para disputar a eleição presidencial. Seu aparente desprezo por qualquer identidade partidária, e a forma como foi eleito com um discurso direto com seu eleitorado, sem a intermediação da estrutura e da capilaridade partidária, corroboram no Brasil a tese de Manin acerca da democracia de público.

O filósofo Slavoj Zizek sintetizou como Bolsonaro construiu a fronteira agonística em seu populismo: "Bolsonaro e seus demagogos populistas de direita foram capazes de mobilizar essa eterna acusação contra Lula, Dilma e seus partidários de que eles seriam os representantes da corrupção, que eles seriam parte de um Estado não transparente, corrupto e por aí vai", observa ${ }^{4}$.

Nos meios tradicionais de massa, Bolsonaro tem uma entrada lateral por meio de programas de auditórios com conteúdo sensacionalista, como CQC, Superpop e Pânico na TV, em que divulga suas ideias polêmicas (PIAIA; NUNES, 2018). Tais ideias são viralizadas na internet, aproximando-se com suas "mitadas" da imagem do troll de internet, figura que ganha adeptos por ridicularizar a opinião dos outros (NUNES, 2020).

Foi, entretanto, por meio das redes sociais que Bolsonaro construiu a narrativa que lhe permitiu alcançar a vitória na eleição presidencial de 2018. Ao pesquisarem dados de 213 grupos públicos de WhatsApp entre 16/08 e 28/10/2018, ou seja,

2. Folha de S. Paulo, 01.10.2018. Disponível em: https://www1.folha.uol.com.br/ilustrissima/2018/10/ elenao-e-parte-do-feminismo-que-vencera-crise-mundial-diz-autora-americana.shtml

3. IHU, 26.11.2018. Disponível em: http://www.ihu.unisinos.br/78-noticias/584930-diante-doavanco-do-populismo-de-direita-o-unico-caminho-e-desenvolver-um-populismo-de-esquerdaentrevista-com-chantal-mouffe

4. Blog da Boitempo, 04.12.2018. Disponível em: https://blogdaboitempo.com.br/2018/12/04/zizek-a-eleicao-de-bolsonaro-e-a-nova-direita-populista/ 
durante o período oficial de campanha estabelecido pelo TSE, Mont'Alverne e Mitozo (2019) observaram que os grupos de apoio para Bolsonaro se mostravam os mais ativos no compartilhamento de informações ao longo da campanha eleitoral. Conforme os dados coletados pelas pesquisadoras, "os apoiadores de Bolsonaro se utilizaram de forma bastante significativa o YouTube em relação ao restante dos analisados (23.475 vezes), os próprios grupos de WhatsApp (4.448 vezes) e o "Jornal da Cidade" (346)" (MONT’ALVERNE; MITOZO, 2019, p. 16). Com um perfil conservador, o site "Jornal da Cidade" foi uma fonte usada quase que exclusivamente por grupos pró-Bolsonaro, com 346 menções dentre as 442 totais nos grupos. Em suas investigações sobre o comportamento coletivo de 90 grupos de WhatsApp interconectados e de apoio aos seis principais presidenciáveis nas eleições de 2018, Aldé et al (2019, p. 315) concluíram que "a apropriação bemsucedida do WhatsApp por apoiadores de Jair Bolsonaro resulta da cooperação de diversos grupos - incluindo eleitores - e um conhecimento específico voltado para viralização sistemática de conteúdo".

Outra rede social, o Twitter, merece atenção, em particular pelo uso expressivo da sua automatização na campanha de Bolsonaro. De acordo com um relatório da Diretoria de Análise de Política Públicas, da Fundação Getúlio Vargas, DAPP/FGV, publicado pouco antes da disputa do segundo turno da eleição presidencial de 2018, a instrumentalização de contas automatizadas no Twitter - os chamados robôs - foi enorme na campanha de Bolsonaro. Para termos ideia da dimensão, das 852,3 mil publicações de robôs identificadas no Twitter entre 10 e 16 de outubro, 602,5 mil vieram da base de apoio de Bolsonaro (RUEDIGER, 2018).

Além dos robôs, outra característica da campanha de Bolsonaro foi o uso intensivo de Fake News ou notícias falsas. Como há dificuldades técnicas para o rastreamento da origem dessas notícias falsas, em particular no WhatsApp, conhecido por ser um sistema criptografado de ponta a ponta, elas avançaram com sucesso sem qualquer controle regulatório. Monitoramento feito pelo jornal El Pais nas eleições de 2018, em três grupos de apoio ao candidato Bolsonaro, identificaram uma série de Fake News que ali circularam com sucesso ${ }^{5}$. Entre as mais compartilhadas estava, por exemplo, a falsa informação de que Manuela d'Ávila, do PCdoB, teria recebido diversas ligações de Adélio Bispo de Oliveira, o criminoso que esfaqueou Bolsonaro. Há também histórias que buscam minar a credibilidade das eleições como a de que códigos das urnas eletrônicas foram passados à Venezuela. Em geral, a origem das Fake News não é rastreável.

5. El Pais, 28.09.2018. Disponível em: https://brasil.elpais.com/brasil/2018/09/26/politica/1537997311_859341.html 
Mas há também as Fake News oficiais, ou seja, notícias falsas divulgadas publicamente. O El Pais menciona como Fake News, por exemplo, um vídeo criado pela então candidata Joice Hasselmann, no qual diz que uma fonte confiável the disse que um órgão de imprensa teria recebido 600 milhões de reais para atacar a campanha de Bolsonaro. Tal denúncia nunca foi confirmada. Outra matéria do El Pais aponta que o próprio filho de Jair Bolsonaro, o deputado federal Eduardo Bolsonaro, foi responsável pela divulgação de Fake News em $2018^{6}$. Em sua conta no Facebook o deputado afirmou que a esquerda comprou uma página com 1 milhão de seguidoras e mudou o nome para mulheres contra Bolsonaro. A notícia, no entanto, era falsa, conforme apurou o El Pais. O grupo "Mulheres Unidas Contra Bolsonaro" foi criado em 30 de agosto de 2018, nunca havia mudado de nome e nunca foi vendido.

O que a campanha de Bolsonaro fez nas redes sociais não foi algo inédito. De fato, a campanha presidencial de Donald Trump pelo Partido Republicano, em 2016, já havia explorado muitas das ferramentas que foram adotadas no Brasil dois anos depois. Em profunda pesquisa sobre o papel das mídias sociais e das Fake News naquelas eleições, Allcott e Gentzkow (2017, p. 212) observaram que 115 histórias falsas que beneficiaram Trump foram compartilhadas no Facebook cerca de 30 milhões de vezes. Esse é, aliás, um ciclo já bem identificado pela literatura especializada. Ituassu (2019) observa que, como a maior parte das tecnologias da informação são desenvolvidas nos Estados Unidos, os profissionais do marketing no Brasil adotam as experiências que já foram testadas no país do norte. Essa é a hipótese da "americanização" das campanhas corrente no campo da Comunicação Política.

Mesmo no Brasil novas tecnologias da informação foram utilizadas de modo semelhante já em 2006. É conhecido o caso da eleição ao Senado no Rio de Janeiro, em 2006, disputada entre Jandira Feghali, do PCdoB, e Francisco Dornelles, do PP. $\mathrm{Na}$ véspera da eleição, telefones celulares contratados com as empresas "TIM" e "OI" receberam a seguinte mensagem via SMS: "Igreja e Ongs pedem que eleitores não votem em Jandira Feghali por a candidata pregar a não existência de Deus e defender o aborto". Uma matéria publicada no jornal Folba de S. Paulo em 03 de outubro de 2006 trazia a seguinte denúncia:

Uma nova forma de propaganda eleitoral pode ter ajudado a influir na última hora, no resultado das eleições para senador do Rio. No sábado e no domingo, véspera e dia da votação, respectivamente, clientes das empresas TIM e OI no Estado receberam em seus

6. El Pais, 17.09.2018. Disponível em: https://brasil.elpais.com/brasil/2018/09/17/politica/1537142202_233134.html 
celulares mensagens que pediam para que eles não votassem na candidata do $\mathrm{PC}$ do $\mathrm{B}$ ao Senado, Jandira Feghali ${ }^{7}$.

A influência das mensagens foi decisiva naquela eleição. Na última sondagem do Datafolha e do Ibope, Feghali aparecia como vitoriosa com muitos pontos de distância em relação ao candidato do PP. Contudo, o vencedor foi Dornelles. O método de mensagens eleitorais via SMS de celular, em 2006, foi bem semelhante ao do WhatsApp em 2018.

Assim como ocorreu em 2006, denúncias na imprensa apontaram que todo esse processo ocorreu de forma ilegal ao longo da campanha presidencial de 2018. O jornal Folha de S. Paulo, em matéria de 18 de outubro de 2018, ou seja, em meio à disputa do segundo turno daquela eleição, denunciou que empresários bancaram a campanha contra o PT pelo WhatsApp com contratos de R\$12 milhões. Entre as empresas envolvidas, segundo a Folba de S. Paulo, estaria a Havan, do empresário Luciano Hang, conhecido apoiador de Bolsonaro. "As empresas apoiando o candidato Jair Bolsonaro (PSL) compram um serviço chamado "disparo em massa", usando a base de usuários do próprio candidato ou bases vendidas por agências de estratégia digital", acusou o jornal ${ }^{8}$. Essa é uma prática ilegal por duas razões: em primeiro lugar, desde a eleição de 2016, a legislação eleitoral proíbe a participação econômica de empresas nas eleições; em segundo lugar, a legislação também proíbe a compra de bases de dados de terceiros.

Foi esse o cenário que impulsionou a instalação, em 04 de setembro de 2019, da Comissão Parlamentar Mista de Inquérito do Congresso Nacional que ficou conhecida como CPI das Fake News. O registro de criação afirma que a sua finalidade é investigar "os ataques cibernéticos que atentam contra a democracia e o debate público" e "a utilização de perfis falsos para influenciar os resultados das eleições $2018^{\prime \prime}$. De forma curiosa, as principais denúncias que surgiram na CPMI partiram de antigos aliados de Bolsonaro como os deputados federais Alexandre Frota e Joice Hasselman. Em seu depoimento, Frota afirmou que havia na campanha de Bolsonaro uma "milícia digital" responsável pelas Fake News ${ }^{10}$. Já Hasselman responsabilizou diretamente o filho do presidente: "as instruções passam muito por Eduardo e assessores ligados a ele. Eles ativam a militância e, depois, publicadores

7. Conjur, 09.10.2006. Disponível em: https://www.conjur.com.br/2006-out-09/jandira_feghali_ adversarios sejam investigados? pagina $=2$

8. Folha de S. Paulo, 18.10.2018. Disponível em: https://www1.folha.uol.com.br/poder/2018/10/ empresarios-bancam-campanha-contra-o-pt-pelo-whatsapp.shtml

9. Senado. Disponível em: https://legis.senado.leg.br/comissoes/comissao?3\&codcol $=2292$

10. UOL, 25.10.2019. Disponível em: https://noticias.uol.com.br/colunas/tales-faria/2019/10/25/frota-confirmara-milicia-bolsonarista-em-depoimento-na-cpi-das-fake-news.htm 
que têm muitos perfis falsos para dificultar a responsabilização das fake news. Para que não haja imputação de crime ou acionamento da Justiça, muitos perfis são falsos", explicou a ex-líder do governo Bolsonaro no Congresso Nacional ${ }^{11}$.

Em síntese, o que observamos é que a estratégia do populismo de direita de Bolsonaro adotou a mídia digital não apenas como canal preferencial de propaganda de suas ideias, mas também para a divulgação das chamadas Fake News. Essas mídias digitais não foram utilizadas de uma forma horizontal, de modo a criar mecanismos de participação política em torno do projeto de Bolsonaro, mas sim de uma forma vertical, em que o eleitorado era apenas um receptor das mensagens. Estratégia diferente, ou seja, mais participativa, foi adotada pelo populismo de esquerda, como veremos a seguir.

\section{POPULISMO DE ESQUERDA: PODEMOS E A PARTICIPAÇÃO VIA REDES SOCIAIS}

A Espanha, desde o início da sua vida democrática, manteve uma grande estabilidade política com a alternância de poder entre dois partidos, o PSOE e o PP. Isso mudou após a crise econômica da zona do Euro, devido ao endividamento dos Estados e seus efeitos na economia espanhola, com perda da moradia, o achatamento dos salários e o desemprego e subemprego da juventude. Para reduzir a dívida, ambos os partidos propunham medidas de austeridade com cortes nos gastos sociais, criando um cenário de descontentamento popular. Em 15 de maio, ocorrem as Acampadas - ocupações - nas principais praças das cidades, significativamente a Plaza del Sol, dando início ao movimento 15-M (CASTELLS, 2013).

O 15-M traz consigo não só um novo discurso, mas uma nova forma de produzi-lo. Em parte, porque o processo se realiza nos espaços autônomos das redes e em parte no espaço público das praças transformadas em palco de discussão. As praças contaram com três novidades básicas: (i) novo repertório político, ao procurar na ocupação das praças e do espaço público seu local de expressão; (ii) o uso das novas tecnologias de informação e comunicação como meio para difundir a sua própria versão, contrária à mídia hegemônica, dos acontecimentos da praça para toda a população, acompanhando as narrativas de cada um dos envolvidos (PLEYERS, 2017) ; e, por fim, (iii) uma organização molecular de demandas a partir

11. Rede Brasil Atual, 04.12.2019. Disponível em: https://www.redebrasilatual.com.br/politica/2019/12/joice-hasselmann-cpi-fake-news/ 
da divisão de eixos temáticos de ação em assembleias autônomas conhecidas como Mareas (CAVA; BELTRÁN, 2015).

Essa nova forma de organização permitida pelas NTICs, segundo Gerbaudo (2017), traz um populismo de princípios horizontais e crítico da representação. Muitas propostas de partido tentam se tornar o veículo dos ideais do 15-M. O mais bem-sucedido será o Podemos que conseguirá em seis meses de criação alcançar a marca de cinco eurodeputados nas eleições para o parlamento europeu (LOPEZ, 2016).

O motivo de seu sucesso é algo muito discutido por seus líderes, como Pablo Iglesias, Iñigo Errejón, Carolina Bescacia e Juan Carlos Monedero, todos professores de ciência política da Universidade Complutense de Madrid. As "hipóteses Podemos" consistiam em: uma renovada interpretação teórica da situação e nos usos dos meios de comunicação.

A interpretação trazida era que a Espanha vivia um momento de latino americanização (IGLESÍAS, 2015). Em especial, Iñigo Errejón, considerado o intelectual do partido em seu início, propunha que o 15-M havia aberto uma crise orgânica na hegemonia, nos moldes do que permitiu a ascensão do MAS na Bolívia. Em leitura baseada nas obras de Laclau e Mouffe, Errejón (2011) apostava na formulação de um novo discurso, capaz de aglutinar as diferentes demandas levantadas pelo $15-\mathrm{M}$ em oposição à política tradicional espanhola. No discurso do Podemos, derivado das acampadas, a disputa se dava entre o povo e a casta política apoiadora de uma agenda de austeridade.

Essa interpretação prescritiva da teoria do populismo contava com o domínio da comunicação política. Nesse cenário, aparece como fundamental o programa televisivo La Tuerka - o parafuso-, no qual Iglesias aparecia em rede nacional criticando a velha política, ao mesmo tempo em que fazia uso de uma estética e um linguajar próprios ao do movimento da Plaza del Sol. É no domínio da linguagem midiática que eles acreditam residir sua novidade. Para avançar com este objetivo o grupo também passou a publicar no Publica.es, jornal diário digital de muita capilaridade na esquerda espanhola. (DELCLÓS, 2015). Haveria de participar como colunistas Pablo Iglesias e Jorge Moruno, escritor espanhol e assessores dos discursos de Iglesias.

Sua presença no cenário político não era bem vista pelas agremiações tradicionais de esquerda (LOPEZ, 2016). Considerado uma figura burlesca, poucos prestaram atenção ao papel a que Iglesias se propunha. Tal aspecto é lido pelas lideranças do partido-movimento como tendo um efeito positivo, pois a não presença de certos setores de esquerda permitiram-nos se valer da estrutura 
crítica do 15-M para reimaginar usos das mídias e redes sociais. La Tuerka tinha seus melhores momentos viralizados na internet e ganhou novas temporadas que podem ser assistidas online.

O grupo em torno de La Tuerka decidiu unir forças com a Izquierda Anticapitalista, agremiação trotskista que teve grande participação nos protestos do $15-\mathrm{M}$ e ajudou a consolidar assembleias locais (LOPEZ 2016). A esses dois grupos uniu-se ainda alguns movimentos sociais mais jovens como a Juventud sin futuro. Em 17 de janeiro de 2014, as principais lideranças do Podemos lançaram seu manifesto Mover la ficha: convertir la indignación en cambio político (2014), no qual o partido se apresenta como um método participativo aberto a todos os cidadãos. Para testar a adesão ao partido, seus líderes propõem que sejam colhidas 50 mil assinaturas pelo site do Podemos. O resultado foi obtido em apenas um dia. Nesse mesmo dia, havia se iniciado o processo de cadastro dos círculos ciudadanos pelo Facebook.

Os círculos eram assembleias locais auto organizadas, que poderiam ter caráter territorial - o bairro - ou temático como pautas identitárias e a questão da moradia. O que começou no Facebook veio a ganhar uma sessão específica no próprio site do partido, onde é possível ver a quantidade de círculos organizados, bem como sua posição geográfica.

Seguindo o 15-M outras inovações de caráter tecnopolítico aparecem. Um aplicativo é criado para se votar as propostas do partido, bem como deliberações públicas foram feitas em um fórum da rede social Reddit chamada Plaza Podemos. A ampliação dos espaços de participação de propostas teve ainda grande impulso dos próprios círculos ciudadanos e das suas votações e discussões internas. Como resultado, as propostas apresentadas e a maneira de sua criação conseguiram convencer a população de que era "o partido dos indignados".

Há, entretanto, diferenças fundamentais entre o partido e o movimento e que tem a ver com o pilar do populismo na organização das redes sociais. Ocorre que a militância do 15-M, com o passar do tempo, passa a fazer uso de alguns aplicativos mais complexos de difícil uso para a população. Além disso, suas reuniões eram em horários difíceis e suas mobilizações cercadas pelos riscos da desobediência civil terminavam por selecionar majoritariamente a classe média precarizada para dentro dos seus meios (DELCLÓS, 2015). O uso da televisão, por meio do programa La Tuerka, coloca em contato o partido com uma população mais envelhecida, o que é importante em um país que já passa pela sua transição demográfica (DELCLÓS, 2015). Por fim, seu objetivo era a construção de uma agenda política de propostas a ser levada adiante para o resto da população poder escolher se participaria ou não dela e não um longo espaço de deliberação. 
Analistas espanhóis que estudaram o movimento consideram que essa estratégia impôs limites a uma posição mais aberta do campo progressista (LOPEZ, 2016, p. 93). Essa tensão se mostra presente no primeiro Congresso de Vistalegre, na disputa entre o grupo da Tuerka e militantes do círculo ligados ao Izquierda Anticapitalista. $\mathrm{O}$ uso de um sistema de votos abertos e virtuais para um rol amplo de candidatos terminou também fortalecendo a ala pablista, cuja popularidade permitiu uma vitória em arrastão de todos os seus apoiadores e das suas propostas políticas (LÓPEZ, 2016, p. 95).

Tal projeto tinha um cunho mais centralista que as outras propostas, concentrando poder na diretoria executiva que poderia até se candidatar politicamente, borrando ainda mais os mecanismos tradicionais dos partidos para impedir a oligarquização política (LÓPEZ, 2016, p. 96). O motivo era poder estruturar uma burocracia de partido rapidamente, capaz de tomar decisões ágeis para ganhar de assalto a política, guiando-se pela mensagem clara e pelo marketing político.

A estratégia trouxe um crescimento meteórico. Em janeiro de 2015, Podemos se apresentava como o segundo partido mais forte, com 23,9\%, perdendo apenas para o Partido Popular. Porém, duas mudanças ocorreram que minaram sua ascensão (LOPEZ, 2016; DELCLÓS, 2015). A primeira foi o uso da mídia para difamar algumas das suas principais lideranças, tal como Errejón por suposta irregularidade no cumprimento de contrato como professor dedicação exclusiva; e de Monedero por receber dinheiro da Venezuela como assessor. Ambas afetaram a imagem de que eram "jovens comportados", parte de seu marketing político, segundo López (2016, p. 100). A segunda foi o surgimento do Ciudadanos, partido espanhol de centro-direita. Apesar de ter um discurso mais conservador, sua estética em torno de jovens lideranças disputa o mesmo eleitorado do Podemos.

Há ainda o problema da superexposição do partido pelo uso das redes sociais como forma de transparência política (DELCLÓS, 2015). As brigas internas do partido passam a ser acompanhadas por todos, sendo o caso dos conflitos entre o grupo de Iglesias e o Izquierda Anticapitalista, de Echenique, e também da grande disputa que se deu entre Iñigo e Iglesias para definir os rumos do partido, o que culminou com a saída de seu maior intelectual.

Seja como for, Podemos e Ciudadanos romperam com a estabilidade política do bipartidarismo espanhol. Atualmente, para se governar é necessário de um dos dois, como se depreende da ascensão de Iglesias ao cargo de vice-primeiro ministro da Espanha, após se firmar uma aliança com o PSOE. 


\section{CONSIDERAÇÕES FINAIS}

Em síntese, a partir dos casos estudados foi possível observar a forte ligação entre as novas mídias e o populismo, em especial pelo uso da comunicação política em mensagens rápidas e simples de apelo popular. Entretanto, apesar de semelhanças na forma discursiva apresentada, foi possível perceber táticas distintas no uso das mídias e nos seus objetivos: uma mais vertical, e a outra, horizontal. $\mathrm{Na}$ análise comparada dos casos de Bolsonaro no Brasil e do Podemos na Espanha, representantes de um populismo de direita e de um populismo de esquerda, respectivamente, observou-se como cada uma dessas práticas políticas lida com as mídias digitais. O populismo de direita brasileiro opera um tipo de mobilização social vertical, baseado em mensagens em redes sociais como Facebook, Whatsapp e Twitter que informa a agenda a ser seguida por seu eleitorado. Sob esse registro, o eleitorado é receptor, mas também divulgador da agenda. Além disso, o populismo de direita de Bolsonaro ativa com intensidade maior do que qualquer outro movimento a prática das Fake News na construção de suas narrativas, de tal maneira a produzir uma fronteira antagônica capaz de rejeitar todo o campo progressista. O populismo de esquerda do Podemos, ao contrário, prefere um tipo de ação horizontal nas redes sociais, com uma preocupação participativa e deliberativa em seu cerne. Dito de outro modo, no caso espanhol estudado, o eleitorado não é mero receptor e divulgador de agenda, mas também construtor da sua formulação.

Importante ressaltar que a pesquisa realizada não permite uma generalização desse tipo de prática no sentido de afirmar que o populismo de direita se relacionará com as mídias digitais sempre verticalmente e o de esquerda, horizontalmente. Novas pesquisas, com um espectro maior de comparação no cenário internacional, são necessárias para a comprovação dessa hipótese.

\section{REFERÊNCIAS}

ALDÉ, Alessandra; SANTOS, João Guilherme Bastos dos; FREITAS, Miguel; SANTOS, Karina; CUNHA, Vanessa Cristine Cardozo. (2019). WhatsApp, política mobile e desinformação: a hidra nas eleições presidenciais de 2018. C\&S - São Bernardo do Campo, v. 41, n. 2, pp. 307-334, maio-ago.

ALLCOTT, Hunt; GENTZKOW, Matthew. (2017). Social Media and Fake News in the 2016 Election. Journal of Economic Perspectives, v. 31, n. 2, pp. 211-236.

BAUMAN, Zygmunt. (2000). Liquid Modernity. Cambridge: Polity Press. 
CASTELLS, Manuel. (2009). Communication Power. $1^{\text {a }}$ ed. New York: Oxford.

CASTELLS, Manuel. (2013). Redes de Indignação e Esperança: movimentos sociais na era da internet. $1^{\text {a }}$. Rio de Janeiro: Zahar.

CAVA, Bruno; BELTRÁN, Sandra Erencón. (2015). Da crise capitalista a reinvenção da democracia na Espanha e na Grécia. In: CAVA, Bruno; BELTRÁN, Sandra Erencón (org.). Podemos e Syriza: Experimentações políticas e democracia no século 21. São Paulo: Annablume.

DELCLÓS, Carlos. (2015). Hopes is a Promise: From the indignados to the rise of Spain. London: Zed books Ltd.

DOMINGUES, José Maurício. (2013). Modernidade Global e Civilização Contemporânea - Para uma renovação da teoria crítica. Belo Horizonte: Editora UFMG.

ERREJÓN, Iñigo. (2011). El 15-M como discurso contrahegemónico. Encrucijadas Revista Crítica de Ciencias Sociales. n. 2.

FRASER, Nancy. (2019). Neoliberalismo progressista versus populismo reacionário: a escolha de Hobson. In: GEISELBERGER, Heinrich. A grande regressão: um debate internacional sobre os novos populismos - e como enfrenta-los. São Paulo: Estação Liberdade.

GRAMSCI, Antonio. (2014). Cadernos do Cárcere. Vol. 5. Trad. Carlos Nelson Coutinho. Rio de Janeiro: Civilização Brasileira.

GRAMSCI, Antonio. (2015). Cadernos do Cárcere. Vol. 6. Trad. Carlos Nelson Coutinho. Rio de Janeiro: Civilização Brasileira.

HALL, Stuart. (1988). The hard road to renewal: thatcherism and the crisis of the left. London - New York: Verso.

HARVEY, D. (2007). A condição pós-moderna: uma pesquisa sobre as origens da mudança cultural. São Paulo: Loyola.

IGLESIAS, Pablo. (2015). Entender Podemos. New Left Review, 93. pp. 9-32. Jul/Ago.

INGLEHART, Ronald. (2001). Modernización y posmodernización: el cambio cultural, económico y político en 43 sociedades. Madrid: Centro de Investigaciones Sociológicas/Siglo Veintiuno.

ITUASSU, Arthur. (2019). A disrupção da esfera pública no Brasil. Insight Inteligência. n. 87. 
LACLAU, Ernesto. (2013). A Razão Populista. 1 ${ }^{\text {a }}$ ed. Trad. Carlos Eugênio Marcondes de Moura. São Paulo: Três Estrelas.

LACLAU, Ernesto; MOUFFE, Chantal. (2015). Hegemonia e estrategia socialista: por uma política democrática radical. São Paulo: Intermeios.

LOPEZ, Emanuel Rodríguez. (2016). La Política en el Ocaso de la Clase Media: El Ciclo 15M Podemos. Madrid: Editora traficante de sueños.

MANIN, Bernard. (1995). As Metamorfoses do Governo Representativo. Revista Brasileira de Ciências Sociais, $\mathrm{n}^{\mathrm{O}} 29$, pp. 5-34.

MONT'ALVERNE, Camila; MITOZO, Isabele. (2019). Muito além da mamadeira erótica: as notícias compartilhadas nas redes de apoio a presidenciáveis em grupos de WhatsApp, nas eleições brasileiras de 2018. Anais do $8^{\circ}$ Compolítica. 15 e 17 de maio de 2019, Universidade de Brasília.

MOUFFE, Chantal. (2019). Por um populismo de esquerda. São Paulo: Autonomia Literária.

NEGRI, Antonio; HARDT, Michael. (2014). Multidão. Rio de Janeiro: Record.

NUNES, Rodrigo. (2015). The Network Prince: Leadership between Clastres and Machiavelli. International Journal of Communication. pp. 3662-3679.

NUNES, Rodrigo. (2020). Alvim errou a mão na trollagem nazi inspirada na direita dos EUA. Folha de S. Paulo. Disponível em: < https://www1.folha.uol.com.br/ ilustrissima/2020/01/alvim-errou-a-mao-na-trollagem-bolsonarista-inspirada-nadireita-dos-eua.shtml>. Acesso: 25/01/2020

PLEYERS, Geoffrey. (2017). Entre las redes sociales y las plazas. In: BRINGEL, Breno; PLEYERS, Geoffrey. Protesta e indignación global: los movimientos sociales en el nuevo orden mundial. $1^{\text {a }}$ ed. Buenos Aires: CLACSO. Rio de Janeiro: FAPERJ.

PIAIA, V. R.; NUNES, R. (2019). Política, entretenimento e polêmica: Bolsonaro nos programas de auditório. In: Carolina de Paula; João Feres Júnior. (Org.). Eleições 2018 e a crise da democracia brasileira. 1ed.Curitiba: Appris, 2019, v., p. 105-110.

PODEMOS. (2014). Mover la ficha: convertir la indignación en cambio político. Disponível em: https://www.cuartopoder.es/alsoldelacalle/files/2014/01/Mover-ficha-convertirlaindignacio\%CC\%81n-en-cambio-poli\%CC\%81tico.pdf. Acessado dia 11/12/16. 
RANCIÈRE, Jacques. (1999). Disagreement: politics and pbilosopby. Minneapolis: University of Minnesota Press.

RUEDIGER, M.A. (2018). A semana nas redes: 18/10/2018. DAPP Report. Disponível em: https://observa2018.com.br/wp-content/uploads/2018/10/18-10-Dapp-Report.pdf

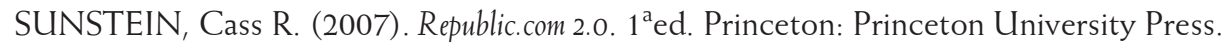

TOURAINE, Alain. (1970). Sociedade Pós-Industrial. Lisboa: Moraes Editores.

Recebido: 31/01/2020

Aceito: 25/03/2020

Publicado: 21/05/2020 